$$
\begin{array}{l|l|l}
\text { Jurnal Eksplorasi Akuntansi } & \text { ISSN : 2656-3649 (Online) } \\
\text { Vol. 2, No 1, Seri A, Februari 2020, Hal 2020-2034 } & \text { http:/jea.ppj.unp.ac.id/index.php/jea/issue/view/17 }
\end{array}
$$

\title{
Pengaruh Ukuran Pemerintah, Pendapatan Per Kapita Dan Leverage Terhadap Keteraksesan Internet Financial Report Oleh Pemerintah Daerah (Studi Empiris Pemerintah Daerah Kabupaten/Kota di Provinsi Sumatera Barat)
}

\author{
Anugerah Akbar Anthony Putra1, Efrizal Syofyan² \\ ${ }^{1}$ Alumni Jurusan Akuntansi Fakultas Ekonomi, Universitas Negeri Padang \\ ${ }^{2}$ Jurusan Akuntansi Fakultas Ekonomi, Universitas Negeri Padang \\ *Korespondensi: anugerahakbaranthony@gmail.com
}

\begin{abstract}
This study aims to analyze 1) How does the size of the government affect the accessibility of internet financial report by the Regency / City Regional Government in West Sumatra Province, 2) How does the income per capita affect the accessibility of internet financial report by the Regency / City Regional Government in the West Sumatra Province, 3) How does leverage affect the accessibility of internet financial report by Regency/City Governments in West Sumatra Province, 4) Does the size of the government, per capita income and leverage jointly affect the accessibility of internet financial report by Regency/City Governments in West Sumatra Province. The results of the study found variables of government size, per capita income and unaffected leverage on the accessibility of internet financial report by the Regency / City Regional Government in West Sumatra Province
\end{abstract}

Keywords: Government Measures, Per Capita Income, Leverage and accessibility Internet Financial Report

How to cite (APA $6^{\text {th }}$ style):

Putra, A.A.A., Syofyan, E. (2020). Pengaruh Ukuran Pemerintah, Pendapatan Per Kapita Dan Leverage Terhadap Keteraksesan Internet Financial Report Oleh Pemerintah Daerah (Studi Empiris Pemerintah Daerah Kabupaten/Kota di Provinsi Sumatera Barat). Jurnal Eksplorasi Akuntansi, 2(1), Seri A. 2020-2034.

\section{PENDAHULUAN}

Penggunaan teknologi informasi dalam penyaluran informasi keuangan melalui media internet (Internet Financial Reporting-IFR) telah dilakukan oleh beberapa pemerintah daerah di Indonesia sebagai salah satu bentuk pertanggungjawaban pengelolaan keuangan daerah kepada para stakeholdernya. Hal ini sesuai dengan Instruksi Menteri Dalam Negeri Nomor 188.52/1797/SJ/2012 tentang Peningkatan Transparansi Pengelolaan Anggaran Daerah yang menginstruksikan kepada Gubernur, Bupati dan Walikota seluruh Indonesia untuk menyiapkan menu konten dengan nama "Transparansi Pengelolaan Anggaran Daerah (TPAD)" dalam website resmi pemerintah daerah serta memuat 12 dokumen pengelolaan anggaran dalam website terkait. Praktik IFR didorong dengan adanya Pasal 13 Peraturan Pemerintah Nomor 65 Tahun 2010 
tentang Perubahan Atas Peraturan Pemerintah Nomor 56 Tahun 2005 tentang Sistem Informasi Keuangan Daerah dan Pasal 2 Undang-Undang Nomor 14 Tahun 2008 tentang Keterbukaan Informasi Publik yang menyatakan bahwa adanya penyajian informasi keuangan daerah melalui situs resmi pemerintah daerah serta setiap informasi publik bersifat terbuka, dan dapat diakses oleh setiap pengguna informasi publik dengan cepat, tepat waktu, biaya ringan dan cara sederhana (Nosihana, 2016).

Styles \& Tennyson (2007) dalam Verawaty (2015) mengungkapkan bahwa internet adalah media yang mudah dijangkau oleh masyarakat dan sarana yang efektif bagi pemerintah untuk mempublikasikan informasi keuangannya secara online. Internet Financial Reporting melalui e-government merupakan media yang paling memenuhi aspek value of money atau 3E (Efisiensi, Efektivitas, dan Ekonomi) untuk menyediakan dan mengumumkan informasi mengenai laporan keuangan kepada semua pemangku kepentingan publik antara lain pemerintah pusat, pemerintah daerah lain, DPRD, BPK, analis ekonomi, investor, kreditur, donatur, dan masyarakat. Informasi yang dibutuhkan oleh institusi publik atas pelaporan keuangan pemerintah daerah adalah informasi kepatuhan terhadap aturan, informasi kinerja, informasi kondisi keuangan dan informasi perencanaan dan penganggaran. Tidak hanya itu, laporan keuangan pemerintah daerah juga harus berkualitas yakni relevan, andal, dapat dibandingkan, serta dapat di pahami oleh penggunanya. Pengungkapan informasi dalam laporan keuangan memiliki dampak ekonomis dan subtansial dalam pengambilan keputusan. Dalam pelaporan keuangan pemerintah daerah, baik pihak eksekutif maupun legislatif sama-sama berkepentingan untuk memastikan bahwa laporan keuangan pemerintah daerah telah memberikan penjelasan yang memadai mengenai kepatuhan terhadap aturan, informasi kinerja, informasi kondisi keuangan, serta informasi perencanaan dan penganggaran (Novia et.al, 2015).

Untuk mewujudkan tercapainya tujuan dalam Undang-Undang Nomor 14 Tahun 2008 tentang Keterbukaan Informasi Publik, pemerintah daerah juga telah didorong untuk membangun situs Pengelolaan Pelayanan Informasi dan Dokumentasi (PPID) sesuai Peraturan Mendagri Nomor 35 Tahun 2010. Namun demikian, implementasi atas instruksi tersebut belum maksimal dan peraturan tersebut telah diubah sesuai perkembangan keadaan dan peraturan perundangundangan saat ini menjadi Peraturan Mendagri Nomor 3 Tahun 2017 tentang Pedoman Pengelolaan Pelayanan Informasi dan Dokumentasi (PPID) Kementerian Dalam Negeri dan Pemerintahan Daerah. Dalam peraturan tersebut menjelaskan terdapat tiga jenis infomasi yang harus dilaporkan oleh pemerintah daerah, yaitu informasi secara berkala (termasuk di dalamnya laporan keuangan pemerintah daerah), serta merta dan setiap saat.

Tabel 1

Penerapan Internet Financial Reporting Pemda 2018 di Indonesia

\begin{tabular}{clccccc}
\hline No & $\begin{array}{c}\text { Pemerintahan } \\
\text { Daerah }\end{array}$ & $\begin{array}{c}\text { Daerah } \\
\text { Otonom }\end{array}$ & $\begin{array}{c}\text { Tidak } \\
\text { Memiliki } \\
\text { Website }\end{array}$ & $\begin{array}{c}\text { Perbaiki } \\
\text { Website }\end{array}$ & $\begin{array}{c}\text { Tidak } \\
\text { Memiliki } \\
\text { Menu TPAD }\end{array}$ & $\begin{array}{c}\text { Memiliki } \\
\text { menu } \\
\text { TPAD }\end{array}$ \\
\hline 1 & Propinsi & 34 & 0 & 1 & 2 & 31 \\
2 & Kota & 93 & 0 & 3 & 36 & 54 \\
3 & Kabupaten & 415 & 7 & 24 & 230 & 154 \\
& Jumlah & 5425 & 7 & 28 & 268 & 239 \\
& Parsentase & $100 \%$ & $1,29 \%$ & $51,7 \%$ & $49,45 \%$ & $44,10 \%$ \\
\hline
\end{tabular}

Sumber : Destya, 2018

Berdasarkan hasil observasi yang dilakukan tanggal 17 sampai 31 Oktober 2018 (tabel 1) dapat disimpulkan bahwa $44.10 \%$ pemerintah daerah telah melakukan transparasi pengelolaan 
anggaran daerah sesuai Instruksi Mendagri Nomor 188.52/1797/SJ/2012, mayoritas pemda yang telah mengungkapkan konten TPAD secara lengkap dengan tahun anggaran terbaru berada di Pulau Jawa, diluar presentase tersebut terdapat 22 website pemda yang sudah membuat menu TPAD namun belum terdapat konten di dalamnya yakni, Kab.Kendal, Kab. Lamongan, Kab. Tulungagung, Kab. Alor, Kab. Belu, Kab. Ende, Kab. Timor Tengah Selatan, Kab. Saby Raijua, Kab. Barito Selatan, Kab.Poso, Kab. Sigi, Kota Palu, Kab.Bantaeng, Kab.Bone, Kab.Luwu, Kab. Pangkajene Kepulauan, Kab. Takalar, Kab. Mamuju Tengah, Kab. Seram Bagian Barat, Kota Tual, Kab. Merauke, Kab. Yahukimo, dan Kab. Sorong.

Namun demikian, menurut Forum Indonesia untuk Transparansi Anggaran (Fitra) mayoritas pemerintah daerah yang belum mengimplementasikan praktik IFR, dikarenakan pengungkapan tersebut lebih bersifat secara sukarela (voluntary disclosure) sebab belum adanya sanksi yang mengikat (Nosihana \& Yaya, 2016).

Tabel 2

Penerapan Internet Financial Reporting Pemda 2018 di Kota dan Kabupaten di Sumatera Barat

\begin{tabular}{|c|c|c|c|c|c|}
\hline No & Pemerintahan Daerah & $\begin{array}{c}\text { Tidak } \\
\text { Memiliki } \\
\text { Website }\end{array}$ & $\begin{array}{l}\text { Perbaiki } \\
\text { Website }\end{array}$ & $\begin{array}{c}\text { Tidak Memiliki } \\
\text { Menu TPAD }\end{array}$ & $\begin{array}{c}\text { Memiliki } \\
\text { menu } \\
\text { TPAD }\end{array}$ \\
\hline 1 & Kabupaten Pesisir Selatan & - & - & $\sqrt{ }$ & \\
\hline 2 & Kabupaten Solok & - & - & $\sqrt{ }$ & \\
\hline 3 & Kabupaten Sijunjung & - & - & & $\sqrt{ }$ \\
\hline 4 & Kabupaten Tanah Datar & - & - & $\sqrt{ }$ & \\
\hline 5 & Kabupaten Padang Pariaman & - & - & & $\sqrt{ }$ \\
\hline 6 & Kabupaten Agam & - & - & & $\sqrt{ }$ \\
\hline 7 & Kabupaten Lima Puluh Kota & - & - & $\sqrt{ }$ & \\
\hline 8 & Kabupaten Pasaman & - & - & $\sqrt{ }$ & \\
\hline 9 & Kabupaten Kepulauan Mentawai & - & - & & $\sqrt{ }$ \\
\hline 10 & Kabupaten Dharmasraya & - & - & & $\sqrt{ }$ \\
\hline 11 & Kabupaten Solok Selatan & - & - & $\sqrt{ }$ & \\
\hline 12 & Kabupaten Pasaman Barat & - & - & & $\sqrt{ }$ \\
\hline 13 & Kota Padang & - & - & $\sqrt{ }$ & \\
\hline 14 & Kota Solok & - & - & $\sqrt{ }$ & \\
\hline 15 & Kota Sawahlunto & - & - & $\sqrt{ }$ & \\
\hline 16 & Kota Padangpanjang & - & - & & $\sqrt{ }$ \\
\hline 17 & Kota Bukittinggi & - & - & $\sqrt{ }$ & \\
\hline 18 & Kota Payakumbuh & - & - & & $\sqrt{ }$ \\
\hline \multirow[t]{3}{*}{19} & Kota Pariaman & - & - & & $\sqrt{ }$ \\
\hline & Jumlah & - & - & 10 & 9 \\
\hline & Parsentase & - & - & $52,6 \%$ & $47,4 \%$ \\
\hline
\end{tabular}

Sumber : Data Diolah Sendiri, 2019

Data di atas memperkuat temuan riset sebelumnya oleh Agustin (2014) bahwa belum seluruh pemkab/pemkot di propinsi Sumatera Barat memanfaatkan menu transparansi pengelolaan anggaran (TPA) dalam website resmi pemerinta daerah untuk mempublikasikan secara lengkap dan konsisten jenis dokumen-dokumen terkait dengan penggunaan anggaran. Meskipun sebagian besar website Kabupaten di Sumatera Barat telah terdapat menu khusus/link bernama TPA (transparansi pengelolaan anggaran) untuk mendownload informasi atau dokumen keuangan dan kinerja tetapi menu khusus dan link tersebut terkadang kosong, tidak memuat secara lengkap, dan tidak dipublikasikan secara konsisten setiap tahunnya. 
Sekretariat Nasional Fitra merilis Survei Keterbukaan Anggaran (Open Budget Survey) menunjukkan bahwa indeks keterbukaan anggaran Indonesia tahun 2017 berada pada level 64 dari 100 poin, yang artinya mengalami peningkatan dibandingkan survey dua tahun sebelumnya sebesar 59, setelah sempat turun pada 2012 sebesar 62 poin (https://tirto.id). Disamping masalah tersebut tingkat pengguna internet di Indonesia berdasarkan hasil survey yang dilakukan oleh Asosiasi Penyelenggaraan Jasa Internet Indonesia (APJII) tahun 2017 mencapai 54,68\% angka tersebut setiap tahunnya terus mengalami peningkatan. Tingginya tingkat penggunaan internet yang di daerah menyebabkan tingginya tekanan masyarakat akan pengungkapan informasi keuangan melalui internet.

Penerapan IFR diharapkan dapat meningkatkan akuntabilitas dan transparansi pemerintah daerah yang tengah menjadi perhatian khusus para pemangku kepentingan pemerintah serta untuk menciptakan good governance \& clean governance. Menurut United Nation Development Program dalam Madiasmo (2009) karakteristik pelaksanaan good government yakni, partisipasi, aturan hukum, transparansi, responsivitas, konsensus, keadilan, efisiensi dan efekivitas, akuntabilitas dan visi strategik. Pelaporan merupakan salah satu tahap penting dalam akuntabilitas publik (Mahmudi, 2011). Akuntabilitas publik dapat dilihat dari seberapa besar tanggung jawab pemerintah daerah kepada seluruh lapisan stakeholdernya terutama kepada masyarakat yang telah memberikan hak kekuasaan kepada pemerintah daerah melaui pengelolaan sumber daya yang ada. Dengan adanya praktik IFR di lingkungan pemerintah daerah diharapkan mampu memberikan distribusi informasi secara merata pada seluruh lapisan stakeholder pemerintah daerah mengingat kendala luasnya kondisi geografis Indonesia sehingga dapat meminimalkan adanya asimetri informasi. Pelaporan keuangan di internet (IFR) sebenarnya merupakan cara pemda agar terlegitimasi (Alhajjriana et al, 2017).

Namun dalam konteks provinsi Sumatera Barat sendiri belum terlihat bahwa transparansi dan akuntabilitas pengelolaan anggaran telah berjalan beriringan/seirama. Riset Agustin dan Arza (2019) menemukan anomali antara akuntabilitas dan transparansi publik terkait dengan manajemen pengelolaan keuangan daerah. Akuntabilitas publik telah meningkat dalam 7 tahun terakhir (2012-2019), dimana seluruh pemerintah kabupaten/kota di propinsi Sumatera Barat mempublikasikan pada website resmi maupun media massa setiap opini WTP dari BPK atas LKPD. Namun perilaku serupa tidak terjadi dalam konteks transparansi publik, dimana hamper setengah dari 19 pemerintah kabupaten/kota di propinsi Sumatera Barat yang bersedia mengungkapkan secara terbatas dokumen-dokumen terkait pengelolaan anggaran daerah (hanya 5-7 dokumen dari total 12 dokumen).

Legitimasi merupakan sebuah persepsi atau asumsi pihak eksternal bahwa suatu organisasi telah berjalan sesuai norma, aturan, dan keyakinan yang berlaku di masyarakat. Dapat diartikan dengan adanya praktik IFR dapat meyakinkan stakehoder pemerintah daerah terhadap kinerja yang telah sesuai dengan aturan yang berlaku. Praktik pelaporan keuangan melaui internet merupakan salah satu upaya pemerintah dalam menciptakan pemerintahan yang bersih dan bebas dari praktek korupsi (good governance \& clean governance) sesuai dengan Peraturan Presiden Nomor 55 Tahun 2012 tentang Strategi Nasional Pencegahan dan Pemberantasan Korupsi Jangka Panjang Tahun 2012-2025.

Namun demikian, menurut laporan Corruption Preceptions Index 2017 Indonesia mendapat nilai 37 dari 100 poin dan menempati peringkat 96 dari 180 negara. Hal tersebut menunjukkan pemerintah daerah di Indonesia belum mencerminkan pemerintahan yang bersih dan bebas dari praktek korupsi. Sedangkan menurut Laporan Survei Indeks Persepsi Korupsi Indonesia oleh Transparency International Indonesia 2017 dilakukan survey terhadap 12 kota 
besar di Indonesia dengan hasil Jakarta Utara sebagai kota terbersih dan Medan sebagai kota terkorup (www.kpk.go.id). Tindakan korupsi yang berlangsung dalam pemerintah daerah dapat menimbulkan krisis kepercayaan stakeholder pemerintah. Oleh karena itu, perlu adanya upaya lebih lanjut dalam optimalisasi IFR sebagai bentuk peningkatan transparansi dan akuntabilitas pemerintah daerah. Manfaat lain dari praktik IFR di lingkungan pemerintah daerah yakni dapat meningkatan partisipasi publik dan pengawasan anggaran terhadap pemerintah daerah dalam menjamin pengelolaan keuangan daerah sesuai aturan.

Praktik IFR sebagai salah satu perwujudan e-government terus dikembangkan di Indonesia, terbukti dengan dikeluarkannya Peraturan Presiden Republik Indonesia Nomor 95 Tahun 2018 tentang Sistem Pemerintahan Berbasis Elektronik (SPBE), yang menjelaskan bahwa untuk mewujudkan tata kelola pemerintahan yang bersih, efektif, transparan, dan akuntabel serta pelayanan publik yang berkualitas dan terpercaya diperlukan integrasi dan efisiensi manajemen sistem pemerintahan berbasis elektronik secara nasional. Hal ini merupakan salah satu bentuk upaya pemerintah dalam merespon tuntutan masyarakat dan sebagai upaya menciptakan good and clean governance.

Penelitian dari perspektif sektor publik yang dilakukan oleh Laswad, et., al (2005) dalam Ikhlas (2015) meneliti faktor leverage, kompetisi politik, kekayaan daerah, visibilitas pers, tipe pemerintahan, dan ukuran otoritas lokal terhadap pelaporan laporan keuangan pemerintah di internet secara sukarela. Hasil penelitian tersebut menunjukkan bahwa leverage, kekayaan daerah, visibilitas pers, dan tipe pemerintahan memiliki pengaruh yang positif sedangkan kompetisi politik dan ukuran otoritas lokal memiliki pengaruh yang negatif. Penelitian Styles dan Tennyson (2007) dalam Ikhlas (2015) menganalisis faktor-faktor seperti ukuran daerah, struktur pemerintahan, kualitas pengungkapan akuntansi, pendapatan per kapita, tingkat utang dan kondisi keuangan kota terhadap tingkat ketersediaan dan keteraksesan laporan keuangan tahunan komprehensif. Hasil penelitian menunjukkan bahwa kota yang lebih besar memiliki kecenderungan melakukan pelaporan keuangan internet. Kota dengan pendapatan per kapita dan tingkat pengungkapan akuntansi yang lebih tinggi cenderung melakukan pelaporan keuangan di internet. Keteraksesan laporan secara positif memiliki hubungan dengan jumlah penduduk, pendapatan per kapita penduduk, tingkat utang dan kondisi keuangan pemerintah kota.

Pemerintah yang memiliki ukuran yang besar akan berdampak pada jumlah program dan pelayanan bagi masyarakat (Giroux and Shields, 1993). Banyaknya program dan pelayanan yang diberikan akan meningkatkan penggunaan sumber daya. Lebih lanjut, ukuran pemerintah yang besar akan memiliki kompleksitas dalam pengelolaan keuangannya sehingga akan meningkatkan pengawasan oleh para stakeholder khususnya masyarakat. Hal tersebut akan berimplikasi pada biaya pengawasan dan pelaporan yang tinggi sehingga untuk menekan biaya monitoring yang tinggi pemerintah harus memilih media yang lebih efektif dan efisien dalam menyampaikan informasi keuangannya. Hasil penelitian Laswad (2005) dalam Ikhlas (2015) menunjukkan pendapatan asli pemerintah daerah berhubungan secara positif terhadap pengungkapan yang lebih atas informasi keuangan pada websitenya. Pendapatan besar yang dimiliki oleh pemerintah daerah mengindikasikan kinerja baik oleh pemerintah daerah. Hal tersebut dapat menunjukkan kemandirian finansial pemerintah daerah dan ketergantungan terhadap pemerintah pusat. Dengan demikian semakin besar pendapatan yang dimiliki oleh pemerintah daerah maka kecenderungan untuk mengungkapkan informasi keuangannya akan semakin besar. Giroux dan Deis (1993) dalam Ikhlas (2015) melaporkan bahwa terdapat hubungan positif yang signifikan antara pendapatan per kapita suatu daerah dengan tingkat pengungkapan laporan keuangan. 
Berdasarkan uraian latar belakang di atas dan masalah yang ditemukan maka penulis tertarik untuk melakukan penelitian lebih lanjut mengenai penilaian kinerja pemerintahan dengan menggunakan analisis rasio dengan judul "Pengaruh Ukuran Pemerintah, Pendapatan Per Kapita Dan Leverage Terhadap Keteraksesan Internet Financial Report Oleh Pemerintah Daerah (Studi Empiris Pemerintah Daerah Kabupaten/Kota di Provinsi Sumatera Barat)”.

\section{REVIU LITERATUR Keagenan}

Dalam Teori keagenan terdapat dua pihak yang melakukan kesepakatan yaitu hubungan yang muncul ketika satu pihak (principal) memberikan/mendelegasikan kewenangan dan tanggung jawab kepada pihak lain (agent) untuk melakukan pengambilan keputusan. Lupia \& McCubbins (2000) dalam Wau \& Ratmono (2015) menyatakan pendelegasian terjadi ketika seseorang atau satu kelompok orang (prinsipal) memilih orang atau kelompok lain (agen) untuk bertindak sesuai dengan kepentingan prinsipal. Hal ini dapat dilihat juga dalam sistem pemerintahan di indonesia.

Banker dan Paxton (1987) Wau \& Ratmono (2015) mengatakan hubungan antara pimpinan pemerintahan/politikus dengan masyarakat/pemilih dapat disebut sebagai hubungan agensi. Pada pemerintahan di indonesia, pemda bertindak sebagai agent yang menyelenggarakan urusan pemerintahan sesuai kepentingan masyarakat selaku principal. Masyarakat selaku principal memberikan amanat kepada pemda untuk menjalankan kegiatan pemerintahan. Pemda selaku agent mempunyai kewajiban untuk melaporkan hasil pelaksanaan pemerintahan kepada masyarakat. Hasil pelaksanaan pemerintahan terkait dengan penggunaan sumber daya yang telah dipercayakan masyarakat sebagai prinsipal adalah dalam bentuk laporan keuangan.

\section{Signaling Theory}

Dari perspektif privat, teori signalling menekankan pentingnya informasi yang dikeluarkan oleh perusahaan terhadap keputusan stakeholder di luar perusahaan seperti investor. Informasi yang disampaikan oleh perusahaan merupakan unsur yang penting dalam memberikan gambaran mengenai kondisi keuangan sekarang dan prediksi kondisi keuangan di masa yang akan datang. Informasi yang disampaikan oleh perusahaan haruslah informasi yang relevan dan akurat sehingga dapat diandalkan oleh stakeholder.

Dari perspektif publik, teori signalling menjelaskan bahwa pemerintah sebagai pihak yang diberi amanat oleh masyarakat berkeinginan menunjukkan sinyal yang baik kepada masyarakat. Pemerintah mendapat tekanan dari masyarakat untuk memberikan informasi mengenai kinerja dan pencapaianpencapaian pemerintah. Teori signalling dapat membantu pemerintah (agen) dan masyarakat (prinsipal) dalam mengurangi asimetri informasi. Pemerintah dapat mengurangi asimetri informasi dengan cara memberikan sinyal kepada masyarakat melalui pengungkapan laporan keuangan yang berkualitas, peningkatan sistem pengendalian intern dan pengungkapan yang lebih lengkap.

\section{Ukuran Pemerintah}

Ukuran pemerintah daerah adalah sebuah skala yang dapat menunjukkan besar kecilnya keadaan Pemerintah Daerah (Hartono, et al., 2014). Ukuran daerah mengacu pada seberapa besar organisasi. Pemerintah daerah dengan ukuran besar sangat diharapkan mampu memberikan pelayanan yang optimal kepada publik. Harapan serta tuntutan terhadap pemerintah daerah akan memacu kinerja pemerintah daerah yang lebih baik. 


\section{Pendapatan Perkapita}

Pendapatan perkapita adalah pendapatan rata-rata suatu penduduk di suatu wilayah. Variable yang digunakan untuk menghitung pendapatan per kapita adalah pendapatan nasional dan jumlah penduduk (Damayanti, 2013).

\section{Leverage}

Leverage adalah penggunaan aset dan sumber dana (source of funds) oleh perusahaan yang memiliki biaya tetap (beban tetap) dengan maksud agar meningkatkan keuntungan potensial pemegang saham (Sartono, 2013:257).

\section{Internet Financial Reporting}

Mendefinisikan IFR sebagai suatu kondisi ketika suatu pemerintahan menyediakan hal-hal berikut ini dalam website pemerintahan : (1) satu set laporan keuangan komprehensif (termasuk footnote dan laporan auditor), (2) terdapat suatu link ke laporan tahunan, (3) terdapat link ke badan keuangan pemerintah. Hunter menjelaskan bahwa IFR merujuk pada penggunaan website pemerintahan dalam menyebarkan informasi tentang performa keuangan pemerintahan

\section{METODE PENELITIAN}

Dalam penelitian ini desain penelitian ini merupakan Desain Kausalitas. Populasi penelitian ini adalah Pemerintahan Daerah Kabupaten/Kota di Provinsi Sumatera Barat. Jumlah kabupaten dan Kota yang ada di Sumatera Barat adalah 19 kota/kabupaten di Sumatera Barat. Data yang digunakan adalah data sekunder Data sekunder tersebut berupa laporan keuangan pemerintah daerah tahun 2017 yang telah diaudit oleh Badan Pemeriksa Keuangan (BPK). Variabel independen menggunakan data yang tersedia pada laporan keuangan pemerintah daerah 2017.

Untuk melihat pengaruh antara variable independent dan dependent maka dengan ini digunakan analisis kuantitatif yaitu berupa teknik analisis regresi berganda dengan rumus sebagai berikut:

Dimana :

$$
\boldsymbol{Y}=a+b_{1} x_{1}+b_{2} x_{2}+b_{3} x_{3}+e
$$

\begin{tabular}{|c|c|}
\hline$Y$ & $=\mathrm{IFR}$ \\
\hline$X_{1}$ & $=$ Ukuran pemerintahan \\
\hline$X_{2}$ & $=$ pendapatan per kapita \\
\hline$X_{3}$ & $=$ leverage \\
\hline & $=$ Konstanta \\
\hline$b_{1}, b_{2}, b_{3}$ & $\begin{array}{l}=\text { Koefisien regresi masing-masing } x \\
=\text { Error term }\end{array}$ \\
\hline
\end{tabular}


Tabel 3

\begin{tabular}{|c|c|c|c|c|}
\hline No & Variabel & Defenisi Operasional & Indikator & Skala \\
\hline 1 & $\begin{array}{l}\text { Keteraksesan IFR oleh } \\
\text { pemerintah daerah }\end{array}$ & $\begin{array}{l}\text { tingkat keteraksesan } \\
\text { dokumen-dokumen laporan } \\
\text { keuangan secara online di } \\
\text { website pemda }\end{array}$ & $\begin{array}{l}\text { Jika Website Pemda } \\
\text { dapat ditemukan pada } \\
\text { halaman pertama } \\
\text { pencarian google dengan } \\
\text { mengetik nama pemda. } \\
\text { Jika hanya diperlukan } \\
\text { tiga kali klik atau kurang } \\
\text { untuk melihat IFR dalam } \\
\text { website Pemda } \\
\text { Jika data IFR dapat } \\
\text { diunduh dalam format } \\
\text { PDF atau HTML } \\
\text { Jika terdapat IFR tahun } \\
\text { sebelumnya dalam } \\
\text { website pemda } \\
\text { Jika terdapat link data } \\
\text { informasi keuangan } \\
\text { (LKPD/APBD) } \\
\text { Jika terdapat search } \\
\text { engine untuk melakukan } \\
\text { pencarian informasi } \\
\text { keuangan } \\
\text { Jika terdapat komponen } \\
\text { LKPD (Neraca, LRA, } \\
\text { LAK dan CALK) dan } \\
\text { APBD } \\
\text { Jika terdapat informasi } \\
\text { kontak } \\
\text { (telepon/fax/email) untuk } \\
\text { mendapatkan data } \\
\text { informasi keuangan }\end{array}$ & Rasio \\
\hline 2 & Ukuran pemerintahan & $\begin{array}{l}\text { Aset pemda dan pendapatan } \\
\text { asli daerah (PAD). Aset } \\
\text { dapat merepresentasikan } \\
\text { ukuran besar kecilnya suatu } \\
\text { pemerintah daerah dan PAD } \\
\text { dapat menunjukkan kinerja } \\
\text { pemerintahan yang baik }\end{array}$ & $\begin{array}{lr}\text { Variabel } & \text { ukuran } \\
\text { pemerintah } & \text { daerah } \\
\text { diproksikan } & \text { dengan } \\
\text { logaritma (ln) total aset } \\
\text { dalam neraca laporan } \\
\text { keuangan pemerintah } \\
\text { daerah }\end{array}$ & Rasio \\
\hline 3 & Pendapatan perkapita & $\begin{array}{l}\text { Produk domestik regional } \\
\text { bruto (PDRB) merupakan } \\
\text { jumlah nilai tambah yang } \\
\text { dihasilkan dibagi dengan } \\
\text { jumlah penduduk daerah } \\
\text { tersebut }\end{array}$ & $\begin{array}{l}\text { Pendapatan perkapita = } \\
\text { Pendapatan nasional } \\
\text { bruto/jumlah penduduk }\end{array}$ & Rasio \\
\hline 4 & Leverage & $\begin{array}{ll}\text { Kemampuan } & \text { perusahaan } \\
\text { menutupi biaya } & \end{array}$ & $D E R=\frac{K E W A J I B A N}{E K U I T A S}$ & Rasio \\
\hline
\end{tabular}




\section{HASIL DAN PEMBAHASAN}

\section{Analisis Regresi Linear Berganda}

Analisis regresi linear berganda digunakan untuk melihat pengaruh variabel bebas terhadap variabel terikat. Variabel bebas yang digunakan dalam penelitian ini adalah ukuran pemerintahan, pendapatan per kapita dan leverage, sedangkan variabel terikat dalam penelitian ini adalah keteraksesan internet financial report. Untuk melihat pengaruh ukuran pemerintahan, pendapatan per kapita dan leverage secara bersama-sama terhadap keteraksesan internet financial report oleh Pemerintahan Daerah Kabupaten/Kota di Provinsi Sumatera Barat disajikan dalam tabel sebagai berikut :

Tabel 4

Hasil Analisis Regresi Linear Berganda

\begin{tabular}{|c|c|c|c|c|c|c|}
\hline \multirow{2}{*}{\multicolumn{2}{|c|}{ Model }} & \multicolumn{2}{|c|}{ Unstandardized Coefficients } & \multirow{2}{*}{$\begin{array}{c}\text { Standardized } \\
\text { Coefficients } \\
\text { Beta } \\
\end{array}$} & \multirow[t]{2}{*}{$\mathrm{t}$} & \multirow[t]{2}{*}{ Sig. } \\
\hline & & B & Std. Error & & & \\
\hline \multirow{4}{*}{1} & (Constant) & 8.941 & 2.747 & & 3.255 & .005 \\
\hline & $\begin{array}{l}\text { ukuran } \\
\text { pemereintah }\end{array}$ & $-2.1640-009$ & .000 & -.535 & -2.242 & .040 \\
\hline & $\begin{array}{l}\text { pendapatan_perka } \\
\text { pita }\end{array}$ & $8.0310-010$ & .000 & .288 & 1.268 & .223 \\
\hline & leverage & -35.833 & 49.306 & -.166 & -.727 & .478 \\
\hline
\end{tabular}

Sumber : Lampiran Hasil Pengolahan Data SPSS, 2019

Hasil analisis regresi linear berganda dapat dibuat persamaan regresi linear berganda sebagai berikut:

$$
\mathrm{KM}=8.941+(-2.1640-009)+8.0310-010+(-35.833)
$$

Dari persamaan di atas maka dapat diinterpretasikan beberapa hal, sebagai berikut :

a. Konstanta sebesar 8.941, artinya jika sebelum ada ukuran pemerintahan, pendapatan per kapita dan leverage nilainya adalah $0(\mathrm{X} 1=\mathrm{X} 2=\mathrm{X} 3=0)$ maka nilai keteraksesan internet financial report oleh Pemerintahan Daerah Kabupaten/Kota di Provinsi Sumatera Barat adalah sebesar konstanta yaitu 8.941 satuan.

b. Koefisien ukuran pemerintahan adalah sebesar -2.1640-009 artinya ukuran pemerintahan berpengaruh negatif terhadap keteraksesan internet financial report oleh Pemerintahan Daerah Kabupaten/Kota di Provinsi Sumatera Barat, dimana jika ukuran pemerintahan meningkat satu satuan maka keteraksesan internet financial report oleh Pemerintahan Daerah Kabupaten/Kota di Provinsi Sumatera Barat meningkat sebesar -2.1640-009 satuan.

c. Koefisien pendapatan perkapita adalah sebesar 8.0310-010 artinya pendapatan perkapita berpengaruh positif terhadap keteraksesan internet financial report oleh Pemerintahan Daerah Kabupaten/Kota di Provinsi Sumatera Barat, dimana jika ukuran pemerintahan meningkat satu satuan maka keteraksesan internet financial report oleh Pemerintahan Daerah Kabupaten/Kota di Provinsi Sumatera Barat meningkat sebesar 8.0310-010 satuan.

d. Koefisien leverage adalah sebesar -35.833 artinya pendapatan perkapita berpengaruh negatif terhadap keteraksesan internet financial report oleh Pemerintahan Daerah Kabupaten/Kota di Provinsi Sumatera Barat, dimana jika leverage meningkat satu satuan maka keteraksesan internet financial report oleh Pemerintahan Daerah Kabupaten/Kota di Provinsi Sumatera Barat meningkat sebesar -35.833 satuan. 


\section{Koefisien Determinan}

Koefisien determinasi berguna untuk melihat kontribusi pengaruh variabel bebas terhadap variabel terikat. Untuk mengetahui seberapa besar kontribusi ukuran pemerintahan, pendapatan per kapita dan leverage terhadap keteraksesan internet financial report oleh Pemerintahan Daerah Kabupaten/Kota di Provinsi Sumatera Barat dapat dilihat pada tabel 4.5 berikut:

\section{Tabel 5}

Uji R Square

\begin{tabular}{lrrrr}
\hline Model & R & R Square & Adjusted R Square & $\begin{array}{c}\text { Std. Error of the } \\
\text { Estimate }\end{array}$ \\
\hline 1 & $.504^{\mathrm{a}}$ & .254 & .114 & 2.979 \\
\hline
\end{tabular}

Sumber : Lampiran Hasil Pengolahan Data SPSS, 2019

Berdasarkan uji Adjusted R-Square ditemukan nilai koefisien determinasi keteraksesan internet financial report oleh Pemerintahan Daerah Kabupaten/Kota di Provinsi Sumatera Barat ditunjukan dengan nilai Adjust $R$ Square sebesar 0,114, hal ini berarti besarnya kontribusi pengaruh ukuran pemerintahan, pendapatan per kapita dan leverage terhadap keteraksesan internet financial report oleh Pemerintahan Daerah Kabupaten/Kota di Provinsi Sumatera Barat $11,4 \%$ sedangkan sisanya dipengaruhi oleh variabel lain.

\section{Pengujian Hipotesis}

\section{Uji t}

Uji t digunakan untuk melihat pengaruh dari manising-masing variabel bebas terhadap variabel independen dengan variabel dependent. Dengan bantuan program SPSS versi 22 diketahui nilai t hitung pada tabel 4.6 sebagai berikut :

Tabel 6

Uji t

\begin{tabular}{llrrrrr}
\hline Model & \multicolumn{2}{c}{ Unstandardized Coefficients } & $\begin{array}{c}\text { Standardized } \\
\text { Coefficients }\end{array}$ & t & Sig. \\
\cline { 2 - 5 } & \multicolumn{1}{c}{ B } & Std. Error & Beta & \\
\cline { 2 - 6 } & (Constant) & 8.941 & 2.747 & & 3.255 & .005 \\
1 & ukuran pemereintah & $-2.1640-009$ & .000 & -.535 & -2.242 & .040 \\
& pendapatan_perkapita & $8.0310-010$ & .000 & .288 & 1.268 & .223 \\
& leverage & -35.833 & 49.306 & -.166 & -.727 & .478 \\
\hline
\end{tabular}

Sumber : Lampiran Hasil Pengolahan Data SPSS, 2019

Berdasarkan hasil analisis menggunakan uji t dapat dijelaskan sebagai berikut :

1. Nilai $\mathrm{t}$ hitung -2.242 dan nilai $(\mathrm{sig}=0,040<0,05)$. Dengan $\mathrm{df}=19-3=16$ diperoleh $\mathrm{t}_{\text {tabel }}$ sebesar 1.729, dari hasil di atas dapat dilihat bahwa thitung $<t_{\text {tabel }}$ atau $-2.242>1.729$, maka variabel ukuran pemerintah berpengaruh negatif terhadap keteraksesan internet financial report oleh Pemerintahan Daerah Kabupaten/Kota di Provinsi Sumatera Barat.

2. Nilai t hitung 1.268 dan nilai $(\mathrm{sig}=0,223>0,05)$. Dengan $\mathrm{df}=19-3=16$ diperoleh tabel sebesar 1.729, dari hasil di atas dapat dilihat bahwa thitung $<\mathrm{t}_{\text {tabel }}$ atau $1.268<1.729$, maka variabel pendapatan per kapita tidak berpengaruh terhadap keteraksesan internet financial report oleh Pemerintahan Daerah Kabupaten/Kota di Provinsi Sumatera Barat.

3. Nilai t hitung $-0,727$ dan nilai $(\operatorname{sig}=0,478>0,05)$. Dengan $\mathrm{df}=19-3=16$ diperoleh tabel sebesar 1.729, dari hasil di atas dapat dilihat bahwa thitung $<t_{\text {tabel }}$ atau $-0,727<1.729$, maka 
variabel leverage tidak berpengaruh terhadap keteraksesan internet financial report oleh Pemerintahan Daerah Kabupaten/Kota di Provinsi Sumatera Barat.

\section{Uji F}

Uji F digunakan untuk melihat pengaruh secara keseluruhan dari variabel independen dengan variabel dependent. Dengan bantuan program SPSS versi 22 diketahui nilai F hitung pada tabel Anova sebagai berikut .

Tabel 7

Hasil Uji Kelayakan (Uji F)

\begin{tabular}{rlrrrrr}
\hline Model & Sum of Squares & df & Mean Square & F & \multicolumn{1}{c}{ Sig. } \\
\hline & Regression & 48.225 & 3 & 16.075 & 1.812 & $.186^{\mathrm{b}}$ \\
1 Residual & 141.975 & 16 & 8.873 & & \\
& Total & 190.200 & 19 & & & \\
\hline
\end{tabular}

Sumber : Lampiran Hasil Pengolahan Data SPSS, 2019

Berdasarkan uji $\mathrm{F}$ diketahui bahwa nilai $\mathrm{F}$ hitung 1.812 dengan nilai signifikansi sebesar 0,186 $(\mathrm{p}<0,05)$. Hal ini berarti secara bersama-sama variabel ukuran pemerintahan, pendapatan per kapita dan leverage tidak berpengaruh terhadap keteraksesan internet financial report oleh Pemerintahan Daerah Kabupaten/Kota di Provinsi Sumatera Barat.

\section{Pembahasan}

Pengaruh Ukuran Pemerintah terhadap Keteraksesan Internet Financial Report

Hasil penelitian ditemukan nilai thitung -2.242 dan nilai $(\mathrm{sig}=0,040<0,05)$. Dengan df $=19-3=16$ diperoleh $t_{\text {tabel }}$ sebesar 1.729, dari hasil di atas dapat dilihat bahwa $t_{\text {hitung }}<t_{\text {tabel }}$ atau $2.242>1.729$, maka variabel ukuran pemerintah berpengaruh negatif terhadap keteraksesan internet financial report oleh Pemerintahan Daerah Kabupaten/Kota di Provinsi Sumatera Barat. Hasil penelitian menunjukkan bahwa ukuran badan publik berpengaruh negatif terhadap penggunaan IFR.

Hasil pengujian hipotesis tersebut menunjukkan bahwa semakin besar ukuran pemerintah, maka semakin rendah pula penggunaan IFR badan publik. Sebaliknya semakin kecil ukuran badan publik, maka penggunaan IFR juga akan semakin besar. Hasil penelitian ini memberi bukti bahwa ukuran badan publik berpengaruh negatif signifikan terhadap penggunaan IFR. Hasil penelitian yang dilakukan oleh Ikhlas (2015), hasil penelitian ditemukan variabel ukuran pemerintah berpengaruh terhadap internet financial report oleh Pemerintahan Daerah. Penelitian lain yang dilakukan olej Wau (2015) ditemukan ukuran pemerintah berpengaruh terhadap internet financial report.

\section{Pengaruh Pendapatan Perkapita terhadap Keteraksesan Internet Financial Report}

Hasil penelitian ditemukan nilai t hitung 1.268 dan nilai $(\operatorname{sig}=0,223>0,05)$. Dengan $\mathrm{df}$ $=19-3=16$ diperoleh $t_{\text {tabel }}$ sebesar 1.729, dari hasil di atas dapat dilihat bahwa $t_{\text {hitung }}<t_{\text {tabel }}$ atau $1.268<1.729$, maka variabel pendapatan per kapita tidak berpengaruh terhadap keteraksesan internet financial report oleh Pemerintahan Daerah Kabupaten/Kota di Provinsi Sumatera Barat. Hasil penelitian yang dilakukan oleh Ikhlas (2015), hasil penelitian ditemukan variabel pendapatan per kapita tidak berpengaruh terhadap internet financial report oleh Pemerintahan Daerah. Penelitian lain yang dilakukan oleh Wau (2015) ditemukan pendapatan per kapita tidak berpengaruh terhadap internet financial report. 
Hasil penelitian membuktikan besarnya pendapatan per kapita tidak memberikan kontribusi terhadap keteraksesan internet financial report oleh Pemerintahan Daerah. Pendapatan per kapita adalah pendapatan rata-rata suatu penduduk disuatu wilayah. Variable yang digunakan untuk menghitung pendapatan per kapita adalah pendapatan nasional dan jumlah penduduk (Damayanti, 2013).

\section{Pengaruh Leverage terhadap Keteraksesan Internet Financial Report}

Hasil penelitian ditemukan nilai t hitung $-0,727$ dan nilai (sig $=0,478>0,05)$. Dengan $\mathrm{df}$ $=19-3=16$ diperoleh $t_{\text {tabel }}$ sebesar 1.729 , dari hasil di atas dapat dilihat bahwa $t_{\text {hitung }}<t_{\text {tabel }}$ atau $0,727<1.729$, maka variabel leverage tidak berpengaruh terhadap keteraksesan internet financial report oleh Pemerintahan Daerah Kabupaten/Kota di Provinsi Sumatera Barat. Hasil penelitian yang dilakukan oleh Abdul (2015), hasil penelitian ditemukan variabel leverage berpengaruh terhadap internet financial report oleh Pemerintahan Daerah.

Hasil penelitian menunjukkan bahwa tingkat utang tidak berpengaruh langsung terhadap penggunaan IFR. Makna hasil pengujian hipotesis tersebut dengan melihat nilai koefisien regresi yang bernilai positif namun tidak signifikan menunjukkan bahwa semakin besar tingkat utang badan publik, maka semakin tinggi pula penggunaan IFR badan publik. Sebaliknya semakin rendah tingkat utang badan publik, maka penggunaan IFR juga akan semakin rendah. Hasil penelitian ini memberi bukti bahwa tingkat utang badan publik tidak berpengaruh positif signifikan terhadap penggunaan IFR. Penelitian ini tidak mendukung agency theory menurut Zimmerman (1977), pengunaan hutang untuk membiayai aktivitas publik merupakan pendorong bagi manajer sektor publik untuk mengurangi biaya hutang. Hal ini dapat diraih dengan IFR karena dengan media internet, pendistribusian laporan keuangan menjadi lebih efisien, efektif, dan ekonomis sehingga agency cost yang timbul dapat diminimalkan.

\section{Pengaruh Ukuran Pemerintahan, Pendapatan Per Kapita Dan Leverage Secara Bersama- Sama Terhadap Keteraksesan Internet Financial Report}

Berdasarkan uji $\mathrm{F}$ diketahui bahwa nilai $\mathrm{F}$ hitung 1.812 dengan nilai signifikansi sebesar $0,186(\mathrm{p}<0,05)$. Hal ini berarti secara bersama-sama variabel ukuran pemerintahan, pendapatan per kapita dan leverage tidak berpengaruh terhadap keteraksesan internet financial report oleh Pemerintahan Daerah Kabupaten/Kota di Provinsi Sumatera Barat. Hasil penelitian yang dilakukan oleh Abdul (2015), hasil penelitian ditemukan bersama-sama variabel ukuran pemerintahan, pendapatan per kapita dan leverage berpengaruh terhadap internet financial report.

Penerapan IFR diharapkan dapat meningkatkan akuntabilitas dan transparansi pemerintah daerah yang tengah menjadi perhatian khusus para pemangku kepentingan pemerintah serta untuk menciptakan good governance \& clean governance. Menurut United Nation Development Program dalam Madiasmo (2009) karakteristik pelaksanaan good government yakni, partisipasi, aturan hukum, transparansi, responsivitas, konsensus, keadilan, efisiensi dan efekivitas, akuntabilitas dan visi strategik.

\section{KESIMPULAN DAN SARAN \\ Kesimpulan}

1. Hasil penelitian ditemukan nilai t hitung -2.242 dan nilai $(\mathrm{sig}=0,040<0,05)$. Dengan $\mathrm{df}=$ 19-3= 16 diperoleh tabel sebesar 1.729, dari hasil di atas dapat dilihat bahwa thitung $<\mathrm{t}_{\text {tabel }}$ atau $-2.242>1.729$, maka variabel ukuran pemerintah berpengaruh negatif terhadap keteraksesan 
internet financial report oleh Pemerintahan Daerah Kabupaten/Kota di Provinsi Sumatera Barat.

2. Hasil penelitian ditemukan nilai t hitung 1.268 dan nilai $(\operatorname{sig}=0,223>0,05)$. Dengan $\mathrm{df}=19$ $3=16$ diperoleh $t_{\text {tabel }}$ sebesar 1.729, dari hasil di atas dapat dilihat bahwa $t_{\text {hitung }}<t_{\text {tabel }}$ atau $1.268<1.729$, maka variabel pendapatan per kapita tidak berpengaruh terhadap keteraksesan internet financial report oleh Pemerintahan Daerah Kabupaten/Kota di Provinsi Sumatera Barat.

3. Hasil penelitian ditemukan nilai t hitung $-0,727$ dan nilai $(\operatorname{sig}=0,478>0,05)$. Dengan df $=19$ $3=16$ diperoleh $t_{\text {tabel }}$ sebesar 1.729 , dari hasil di atas dapat dilihat bahwa $t_{\text {hitung }}<t_{\text {tabel }}$ atau $0,727<1.729$, maka variabel leverage tidak berpengaruh terhadap keteraksesan internet financial report oleh Pemerintahan Daerah Kabupaten/Kota di Provinsi Sumatera Barat.

4. Berdasarkan uji $\mathrm{F}$ diketahui bahwa nilai $\mathrm{F}$ hitung 1.812 dengan nilai signifikansi sebesar 0,186 ( $\mathrm{p}<0,05)$. Hal ini berarti secara bersama-sama variabel ukuran pemerintahan, pendapatan per kapita dan leverage tidak berpengaruh terhadap keteraksesan internet financial report oleh Pemerintahan Daerah Kabupaten/Kota di Provinsi Sumatera Barat.

\section{Saran}

1. Peneliti dapat mengembangkan penelitian dengan mempertimbangkan variabel lainnya yang dianggap mampu mempengaruhi keteraksesan internet financial report seperti tingkat penetrasi internet, alokasi belanja daerah untuk teknologi informasi, tingkat investasi, kompetisi politik, dan visibilitas media

2. Pada pendapatan per kapita terlihat tidak terdapat pengaruh terhadap keteraksesan internet financial report oleh sebab itu sebaiknya dicari variabel lain yang memberikan kontribusi yang lebih signifikan terhadap keteraksesan internet financial report.

3. Peneliti dapat menambah sampel penelitian seperti badan publik, pemerintah provinsi atau pengambilan sampel Pemda yang mewakili 34 provinsi di Indonesia serta menggunakan periode tahun yang lebih lama untuk melihat perkembangan yang ada

4. Sebaiknya penelitian ini bisa jadi masukan bagi peneliti berikutnya dengan menambah variabel lain dan objek penelitian yang berbeda.

\section{DAFTAR PUSTAKA}

Agustin, Henri; Arza, Fefri Indra. (2019). Potrait of Accountability and Transparency in Local Budget Management by the Regional Government in West Sumatera Province, Indonesia: An Anomaly in Digital Era. $4^{\text {th }}$ Padang International Conference on Education, Economics, Business and Accounting (PICEEBA-2 2019). Padang. 154-166.

Agustin, Henri. (2014). Publikasi Dokumen Pengelolaan Anggaran pada Website Pemkab/Pemkot di Propinsi Sumatera Barat. Seminar Nasional Aplikasi Teknologi Informasi (SNATI). Yogyakarta.

Ashbaugh, Hollis, Karla M. Johstone, dan Terry D. Warfield. (2016). Corporate Reporting on the Internet. Accounting Horizons. 13(3):241-257.

Afryansyah, Rahmad D dan Haryanto. (2013). Faktor-Faktor yang Mempengaruhi Pengungkapan Informasi Akuntansi di Internet oleh Pemerintah Daerah. Diponegoro Journal of Accounting, 2(3)

Damayanti, K. (2013). Internet Financial Reporting (IFR)dan Reaksi Pasar. Skripsi. Universitas Kristen Satya Wacana, Salatiga. 
Destya. (2018). Determinan Praktik Internet Financial Reporting (IFR) dalam Website Pemerintah Daerah (Studi pada Pemerintah Kabupaten/Kota di Indonesia Tahun 20162017)

Hanafi. (2014). Manajemen Keuangan. Yogyakarta: BPFE UGM

Hartono, R, A. Mahmud dan N.S. Utaminingsih. (2014). Faktor-Faktor yang Mempengaruhi Kelemahan Pengendalian Internal Pemerintah Daerah. Proceeding Simposium Nasional Akuntansi XVII. Mataram. Lombok; 1-13.

Hilmi, A.K,. dan Martani, D. (2013). Analisis Faktor-Faktor yang Memengaruhi Tingkat Pengungkapan Laporan Keuangan Pemerintah Provinsi.Simposium Nasional Akuntansi XV Banjarmasin.

Ikhlas. (2015). Faktor-faktor yang Mempengaruhi ketersediaan dan keteraksesan internet financial reporting (IFR) oleh Pemerintah Daerah

Junarwati et al. (2013). Pengaruh Pendapatan Asli Daerah Terhadap Kinerja Keuangan Daerah Pada Kabupaten/Kota Di Provinsi Aceh Tahun 2010-2012. Jurnal Telaah\& Riset Akuntansi, 6(2) : 186-193.

Junaedi. (2015). Pengaruh Kekayaan Pemerintah Daerah, Ketergantungan Daerah, Kompleksitas, Tipe Pemerintah Daerah, Kualitas Audit Dan Tingkat Penyimpangan Anggaran Terhadap Pengungkapan Internet-Based Financial Reportin. Jurnal Sainstech Politeknik Indonusa Surakarta, 2(4)

Laswad, Fawzi dkk. (2005). Determinants of Voluntary Internet Financial Reporting by Local Government Authorities. Journal of Accounting and Public Policy, 24; 101-121.

Madiasmo. (2009). Akuntansi Sektor Publik. Yogyakarta: Penerbit Andi.

Mahmudi. (2011). Akuntansi Sektor Publik. Yogyakarta: UII Press.

Maiyora. (2015). Pengaruh Karakteristik Pemerintah Daerah Terhadap Kinerja Keuangan Pemerintah Darah Kabupaten/Kota (Studi Empiris Kabupaten/Kota Di Pulau Sumatera). Faculty of Economics Riau University. Jom FEKON, 2(2).

Manullang, M.S.G., Sinarwati, N.K. \& Yuniarta, G.A., (2014). Pengaruh Internet Financial Reporting Dan Tingkat Pengungkapan Informasi Berbasis Website Terhadap Frekuensi Perdagangan Saham Perusahaan (Studi Pada Perusahaan Pertambangan Yang Terdaftar. $1(1)$.

Medina, F. (2012). Faktor-Faktor yang Memengaruhi Transparansi Informasi Keuangan Pada Situs Resmi Pemda. Penelitian FEUNDIP 2012.

Muhayanah. 2016. Pengaruh Pendapatan Asli Daerah, Dana Perimbangan Dan Belanja Modal Terhadap Kinerja Keuangan Pemerintah Daerah Kabupaten dan Kota Di Provinsi Jawa Tengah Tahun 2012-2013. Naskah Publikasi. Universitas Muhammadiyah Surakarta.

Nosihana \& Yaya. (2016). Internet Financial Reporting Dan Faktor-Faktor Yang Mempengaruhinya Pada Pemerintah Kota Dan Kabupaten Di Indonesia. Jurnal Dinamika Akuntansi Dan Bisnis, 3(2): 89-104.

Novianti et al. (2016). Pengaruh Ukuran Legislatif, Karakteristik Pemerintah Daerah Dan Temuan Audit Bpk Terhadap Kinerja Pemerintah DaerahKabupaten/Kota Provinsi Sumatera Barat. E-Jurnal Bunghatta, 9(1).

Novia, Siswita; Arza, Fefri Indra; Agustin, Henri. (2015). Studi Kebutuhan Informasi Pengguna Laporan Keuangan Pemerintah Kota Padang (Studi Empiris pada DPRD dan SKPD Kota Padang). Jurnal WRA, 3(1), 529-548. 
Puspita dan Martani. (2012). Analisis Pengaruh Kinerja Dan Karakteristik Pemda Terhadap Tingkat Pengungkapan Dan Kualitas Informasi Dalam Website Pemda. Simposium Nasional Akuntansi XV Banjarmasin, 1-25,September 2012

Rahman, A., Sutaryo, dan Budiatmanto, A. (2013). Determinan Internet Financial Local Government Reporting di Indonesia. Simposium Nasional Akuntansi XVI,Manado, 25-28 September 2013.

Rahman, Sutaryo dan Budiatmanto. (2014). Determinan Internet Financial Local Governmen Reporting di Indonesia. Simposium Nasional Akuntansi XVI Manado.

Ratmono dan Iklas Wau. (2015). Analisi Faktor-faktor Yang Mempengaruhi Ketersediaan Dan Keteraksesan Internet Financial Reporting Oleh Pemerintah Daerah. Diponogoro Jurnal of Accounting. 4(4)

Sari. (2016). Pengaruh Ukuran Pemerintah Daerah, Pad, Leverage, Dana Perimbangan Dan Ukuran Legislatif Terhadap Kinerja Keuangan Pemerintah Daerah (Studi pada Kab/Kota Pulau Sumatra). Faculty of Economics Riau University. JOM Fekon, 3(1).

Sartono, Agus. (2013). Manajemen keuangan teori, dan aplikasi. Yogyakarta: BPFE Yogyakarta.

Sumarjo. (2010). Pengaruh Karakteristik Daerah terhadap Kinerja Keuangan Pemerintah Daerah. Skripsi. Surakarta: Fakultas Ekonomi Universitas Sebelas Maret.

Sesotyaningtyas. (2012). Pengaruh Leverage, Ukuran Legislatif,Intergovernmental Revenue dan Pendapatan Pajak Daerah terhadap Kinerja Keuangan Pemerintah Daerah (Studi Empiris pada Pemerintah Daerah Kabupaten/Kota di Jawa). Skripsi. Semarang: Fakultas Ekonomi. Universitas Negeri Semarang

Syamsudin, Lukman. (2015). Manajemen Keuangan Perusahaan (Konsep Aplikasi Dalam Perencanaan, Pengawasamn, dan Pengambilan Keputusan). Jakarta: PT.Raja Grafindo Persada.

Trisnawati, Mya Dewi dan Komarudin Achmad. (2014). Determinan Publikasi Laporan Keuangan Pemerintah Daerah Melalui Internet. Jurnal Universitas Brawijaya.

Trisnawati, M,D., \& Achmad, K,. (2014). Determinan Publikasi Laporan Keuangan Pemda melalui Internet. Simposium Nasional Akuntansi XVII. Mataram. Lombok.

Verawaty. (2015). Determinan Aksesibilitas Internet Financial Reporting Melalui E-Government Pemerintah Daerah Di Indonesia. Simposium Nasional Akuntansi XVIII Medan, September 2015.

Wau, I., \& Ratmono. (2015). Analisis Faktor-Faktor Yang mempengaruhi Ketersediaan Dan Keteraksesan Internet Financial Reporting Oleh Pemerintah Daerah. Diponegoro Journal of Accounting, 4(4): 1-12. 